\title{
Erratum to: Early laparoscopic cholecystectomy is superior to delayed acute cholecystitis: a meta-analysis of case-control studies
}

\author{
Amy M. Cao ${ }^{1} \cdot$ Guy D. Eslick ${ }^{1} \cdot$ Vinayak Nagaraja $^{1} \cdot$ David Ma $^{1} \cdot$ Michael R. Cox $^{1}$
}

Published online: 18 August 2015

(c) Springer Science+Business Media New York 2015

\section{Erratum to: Surg Endosc}

\section{DOI 10.1007/s00464-015-4325-4}

The following two authors were inadvertently omitted:

Vinayak Nagaraja and David Ma.

Springer regrets the error.

The online version of the original article can be found under doi:10.1007/s00464-015-4325-4.

Guy D. Eslick

eslickg@med.usyd.edu.au

Michael R. Cox

coxmr@bigpond.net.au

1 The Whiteley-Martin Research Centre, Discipline of Surgery, Nepean Hospital, The University of Sydney, Level 5, South Block, P.O. Box 63, Penrith, NSW 2751, Australia 